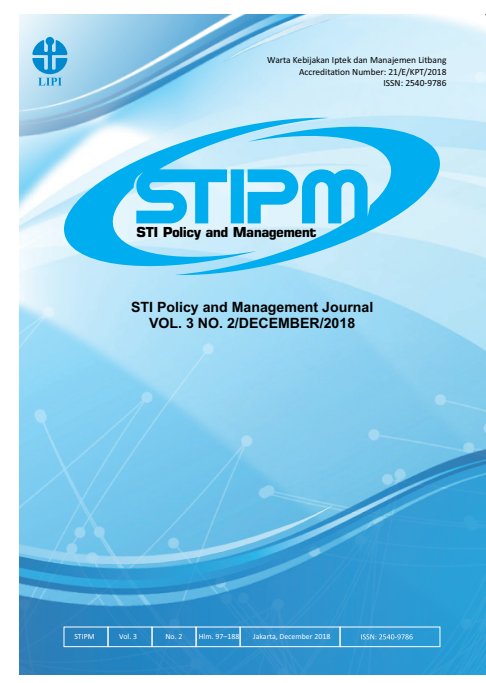

Journal of STI Policy and Management

Publication details, including instructions for authors and subscription information: http://www.stipmjournal.org/

\title{
Drivers of Innovation Without Formal R\&D: Selected Cases of Indonesian Firms
}

\section{Erman Aminullah, Trina Fizzanty, Qinan M.B. Soesanto}

Research Center for Science and Technology Development, Indonesian Institute of Sciences

Version of record first published: 15 December 2018

To cite this article: Aminullah, E., Fizzanty, T., and Soesanto, Q.M.B. (2018). Drivers of Innovation Without Formal R\&D: Selected Cases of Indonesian Firms. Journal of STI Policy and Management, 3(2), 119-136

To link to this article: http://dx.doi.org/10.14203/STIPM.2017.130

ISSN 2540-9786 (Print); ISSN 2502-5996 (online)

Accreditation Number: 21/E/KPT/2018

Full terms and conditions of use: https://creativecommons.org/licenses/by-nc-sa/4.0/

You are free to:

- Share : copy and redistribute the material in any medium or format

- Adapt : remix, transform, and build upon the material

- The licensor cannot revoke these freedoms as long as you follow the license terms.

Under the following terms: Attribution - You must give appropriate credit, provide a link to the license, and indicate if changes were made. You may do so in any reasonable manner, but not in any way that suggests the licensor endorses you or your use.

$\$$ NonCommercial - You may not use the material for commercial purposes.

(2) ShareAlike - If you remix, transform, or build upon the material, you must distribute your contributions under the same license as the original.

No additional restrictions - You may not apply legal terms or technological measures that legally restrict others from doing anything the license permits.

Notices:

- You do not have to comply with the license for elements of the material in the public domain or where your use is permitted by an applicable exception or limitation.

- No warranties are given. The license may not give you all of the permissions necessary for your intended use. For example, other rights such as publicity, privacy, or moral rights may limit how you use the material.

- If you copy the dataset merely to extract the uncopyrightable data elements would not need permission to do so. However, if you republish the full dataset or using the copyrightable data layers require a permission from PAPPIPTEK-LIPI. 


\title{
JOURNAL OF SCIENCE, TECHNOLOGY, AND INNOVATION POLICY AND MANAGEMENT (STIPM JOURNAL), Volume 03, Number 02, December 2018
}

\author{
FOREWORD by EDITOR-in-CHIEF
}

We are very pleased to inform the readers that Journal of Science, Technology, \& Innovation Policy and Management (STIPM Journal) Vol. 3, No. 2, December 2018 is now ready for public reading and views. STIPM Journal is an online research journal, managed by the Center for Science and Technology Development Studies, Indonesian Institute of Sciences (PAPPIPTEK-LIPI).

This journal in fact provides scientific information needed mostly by research scholars. As a peer reviewed journal, STIPM provides free public access to all articles. Two issues, namely scientific review on variables and dimensions of national innovation capability, as well as research findings on development and adoption of science, technology, and innovation policy and management from Japan and Indonesia, are presented.

The first article "Internal Innovation Capacity and External Lingkages in Firms of ASEAN Economies Focusing on Endogeneity" is composed by Masaru OGAWA et al. This research article examines the role of internal innovation capacity, which includes technological level, organizational learning, and human resources on innovation. The second research article entitled "Drivers of Innovation without Formal R\&D: Selected Cases of Indonesian Firms". This article is presented by Erman AMINULLAH et al. The objective of this research study is to obtain a deep understanding about "why and how" firms engaging in innovation without formal $\mathrm{R} \& \mathrm{D}$, through deep analysis of three cases of firms in machinery and food processing sectors.

Uruqul Nadhif DZAKIY presents an article entitled "Technology-based Start-up: A Formula to become Sustainable Company in Indonesia, Lessons-learned from UAVINDO Nusantara". UAVINDO is a sample of technology-based company in Indonesia which has the characteristics of sustainable company. The fourth article entitled "Development Strategy of National Microsatellite Industry: Case Study of Indonesia", is presented by Chusnul Tri JUDIANTO et al. By applying SWOT and Quantitative Strategic Planning Matrix (QSPM) methods, this research identifies and analyzes the alternative strategy from external and internal factors and selects the appropriate and precise strategy for developing the microsatellite industry.

Hadi KARDOYO et al. present an article entitled "Knowledge Accumulation-based Entrepreneurship in the Creative Industry: A Case Study of Woodwork Firms in Indonesia." This article describes the activities of knowledge-entrepreneurship in four wood craft firms, namely Radio Magno, Stranough Guitar Technologi, Secco Guitar, and Matoa Watch, and also shows some lessons from Knowledge Intensive Entrepreneur (KIE). The last article composed by Ahmad Dading GUNADI et al. presents a "Scientifc Review on National Capability Variables and Dimensions." This paper analyses the dimensions and variables of National Innovation Capability through a system approach that includes three sub-systems, namely Input, Process, and Output. 
After indexing by Google Scholar, ISJD and IPI, STIPM Journal is now indexed with DOAJ, BASE, and OCLC World Cat. This has made the journal's dissemination broader. We would like to express our immense gratitude to our international editorial board members, reviewers and authors for their contribution to this issue. We hope this publication will prove useful for readers and could contribute to the enhancement of science, technology and innovation innitiatives. We expect that STIPM will always provide a higher scientific platform for authors and readers, with a comprehensive overview of the most recent STI Policy and Management research and development at the national, regional dan international levels. Finally, wishing you a HAPPY NEW YEAR 2019. May your New Year be filled with great achievements, good health, peace, happines, and joy.

Jakarta, December 2018

Editor-In-Chief 



\section{JOURNAL OF STI POLICY AND MANAGEMENT}

Volume 3, Number 2, December 2018

\section{LIST OF CONTENTS}

Internal Innovation Capacity and External Linkages in FIRMS of ASEAN Economies Focusing on Endogeneity

Masaru Ogawa, Yasuhi Ueki, Hiroki Idota, Teruyuki Bunno, and Masatsugu Tsuji

Drivers of Innovation Without Formal R\&D: Selected cases of Indonesian firms

Erman Aminullah, Trina Fizzanty, Qinan M.B. Soesanto.

Technology-Based Startup: A Formula to Become Sustainable Company in Indonesia a Case Study from UAVINDO Nusantara

Uruqul Nadhif Dzakiy

Development Strategy of National Microsatellite Industry: Case Study of Indonesia

Chusnul Tri Judianto, Harianto, and Agus Maulana

Knowledge Accumulation-Based Entrepreneurship (KABE) in the Creative Industry: A Case Study of Woodwork Firms in Indonesia

Hadi Kardoyo, Setiowiji Handoyo, and Anugerah Yuka Asmara $161-173$

National Innovation Capability Variables and Dimensions

Ahmad Dading Gunadi, Yandra Arkeman, Rizal Syarief Siaiful Nazli, Teguh Rahardjo, and Aulijati Wachjudiningsih. 


\title{
in STI POLICY AND MANAGEMENT \\ LIPI Journal homepage: http://www.stipmjournal.org
}

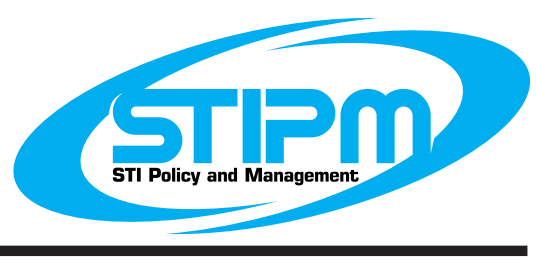

\section{Drivers of Innovation Without Formal R\&D: Selected Cases of Indonesian Firms}

\author{
Erman Aminullah, Trina Fizzanty, Qinan M.B. Soesanto
}

"Research Center for Science and Technology Development, Indonesian Institute of Sciences (PAPPIPTEK-LIPI)

\begin{tabular}{|c|c|}
\hline ARTICLE INFO & ABSTRACT \\
\hline $\begin{array}{l}\text { Article History: } \\
\text { Received : } 19 \text { January } 2018 \\
\text { Revised : } 30 \text { November } 2018 \\
\text { Accepted : } 02 \text { December } 2018 \\
\text { Available online : } 15 \text { December } 2018\end{array}$ & $\begin{array}{l}\text { The objective of this study is to obtain a deep understanding on "why } \\
\text { and how" firms could engage in innovation without formal R\&D. } \\
\text { Three cases studied are firms in machinery and food processing } \\
\text { sectors. The cross cases analysis found that types and sources of } \\
\text { innovation vary according to business areas, technology field and }\end{array}$ \\
\hline $\begin{array}{l}\text { Keywords: } \\
\text { Innovation drivers } \\
\text { Innovation types } \\
\text { Innovation sources } \\
\text { Non-R\&D } \\
\text { Informal R\&D }\end{array}$ & $\begin{array}{l}\text { technological capability level of each firms. The studied firms } \\
\text { demonstrated that innovation could be done through particular } \\
\text { ways, driven by firm's specific resources, namely management } \\
\text { vision and leadership, integrated business system, entrepreneurship } \\
\text { and networking. The conceptual contribution of this study is an } \\
\text { enrichment of "learning by using" with a new variant, the so-called } \\
\text { "mastering by using". Nevertheless, innovation without formal R\&D } \\
\text { is deficient in absorptive capacity (AC), it implies that non-R\&D } \\
\text { and informal R\&D firms should invest in R\&D to develop AC and } \\
\text { increase adoption of progressive technology. Goverment policy } \\
\text { to provide R\&D financing support and tax incentives should be } \\
\text { directed at the innovative low-tech (LT) as well as low and medium- } \\
\text { tech (LMT) industries, which will have produced higher results } \\
\text { through innovation with informal and/or non R\&D activities. }\end{array}$ \\
\hline
\end{tabular}

(C2018 PAPPIPTEK-LIPI All rights reserved

\section{INTRODUCTION}

\section{A. Background and Objective}

Innovation without formal R\&D applies not only to developing countries but also occurs in the developed countries. Almost half of the European firms innovated with engaging neither in-house R\&D nor the R\&D innovators. These firms innovated through contract $R \& D$, creative activities that did not involve $\mathrm{R} \& \mathrm{D}$, or through the adoption

\footnotetext{
* Corresponding Author.

E-mail: aminullahe@yahoo.com
}

of technology (Huang, Arundel, \& Hollanders, 2011). Moreover, Hirsch-Kreinsen and Jacobson (2008) explained that low-tech firms and industries achieved respectable growth in productivity by generating substantial innovation themselves (though these activities may not be captured in R\&D statistics). Some emerging countries in ASEAN has increased productivity with low R\&D intensity (below $0.5 \%$ of GDP), while the Indonesian Innovation Survey conducted by Pappiptek-LIPI (2013) revealed that only $32 \%$ of Indonesian businesses innovation were obtained 
by conducting R\&D. Dominant role of innovation without formal $R \& D$ in Indonesia was revealed by the following statistical evidences.

\section{1) Sectoral Growth of Economy and Low- Tech Industrial Output}

The Indonesian economy has continued to grow positively since the economic crisis in 1997. The economy grew around 5\% in the period of 2001-2012. The sectoral growth was dominated by tertiary sectors (water, gas, electric, construction and other services). The contribution of industrial sector to the economy has been relatively constant at around $30 \%$, with yearly growth around $5 \%$ in the same period.

Seen from the composition of industrial outputs by technological categories, the Indonesian industrial outputs have constantly been around $50 \%$ contributed by low-tech industries, such as recycling, wood, pulp, paper, paper products, printing and publishing, food products, beverages and tobacco, textiles, textile products, leather and footwear. With the exception for the 2009-2012 period, there has been a decrease in the share of low-tech industries which were substituted by the increase of medium-low-tech industries, such as building and repairing of ships and boats, rubber and plastic products, coke, refined petroleum products and nuclear fuel, and other non-metallic mineral products (see Figure 1).

\section{2) Economic Growth with Low R\&D Intensity}

Viewed from input indicators, Indonesia has been in low R\&D intensity during the last 30 years. The stagnant expenditure on $R \& D$ in Indonesian economy was shown by national $R \& D$ intensity that continued to fall steadily from $0.54 \%$ in 1982 to around $0.08 \%$ of GDP in 2010 . The industrial R\&D expenditure was only around $0.013 \%$ of GDP that contributed to around $20 \%$ of national $R \& D$ in 2010. Meanwhile, the government R\&D expenditure (not included $R \& D$ expenditure in higher education) was around $0.067 \%$ of GDP; it covered up to $80 \%$ of national R\&D activity. However, it has little or almost no meaning due to the rare production of commercial innovation.

The Indonesian economy continued to grow despite the continued decline of its national $R \& D$ intensity. For the period of 1990-2010, GDP rose 30 fold at nominal value and grew constanly $7 \%$ before the crisis, then 5\% after the crisis of 1997. On the other hand, national R\&D expenditure rose 16 fold, but R\&D intensity constantly declined from $0.13 \%$ in 1990 to $0.08 \%$ of GDP in 2010 . (Pappiptek-LIPI, 2013; see Figure 2).

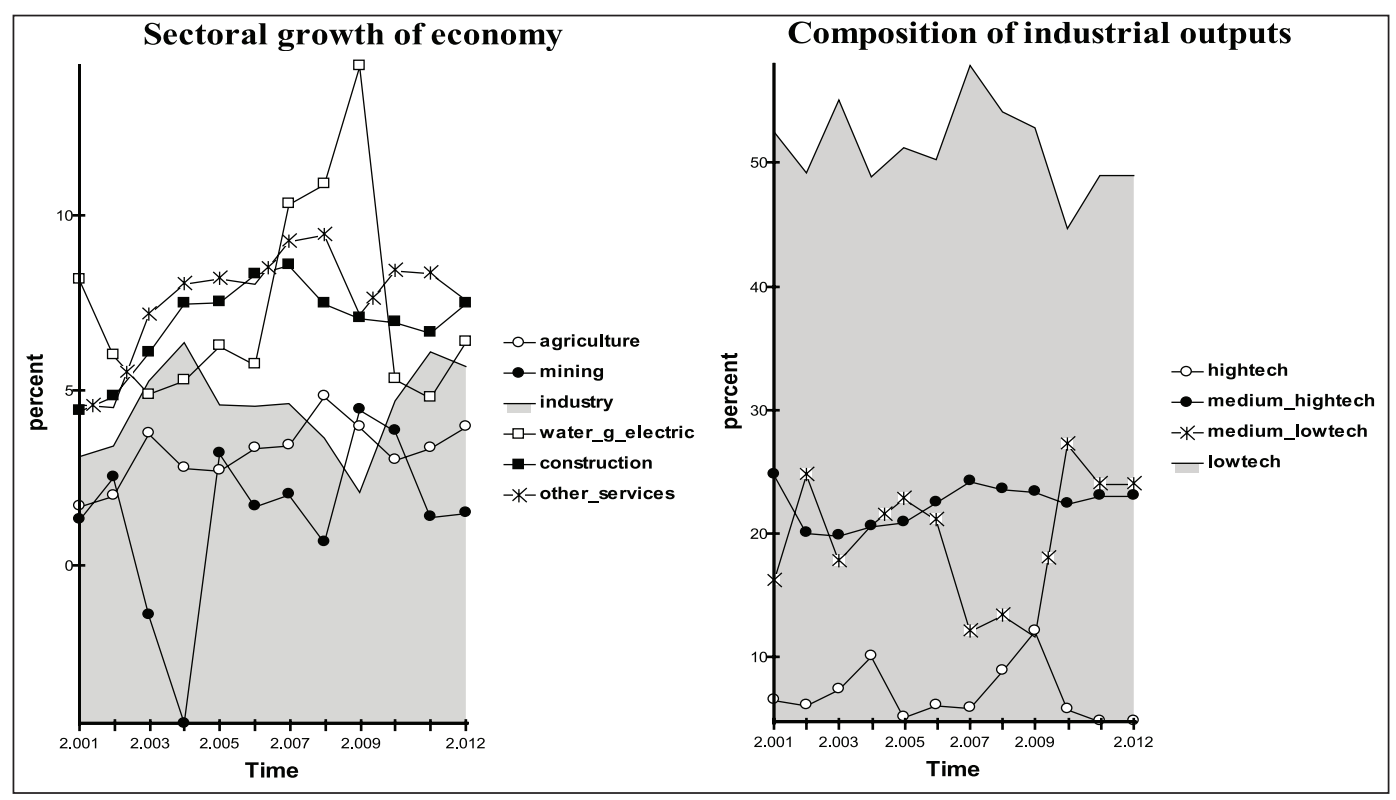

Source: Papipptek-LIPI (2014)

Figure 1. Sectoral Growth of Economy and Industrial Output (2001-2012) 


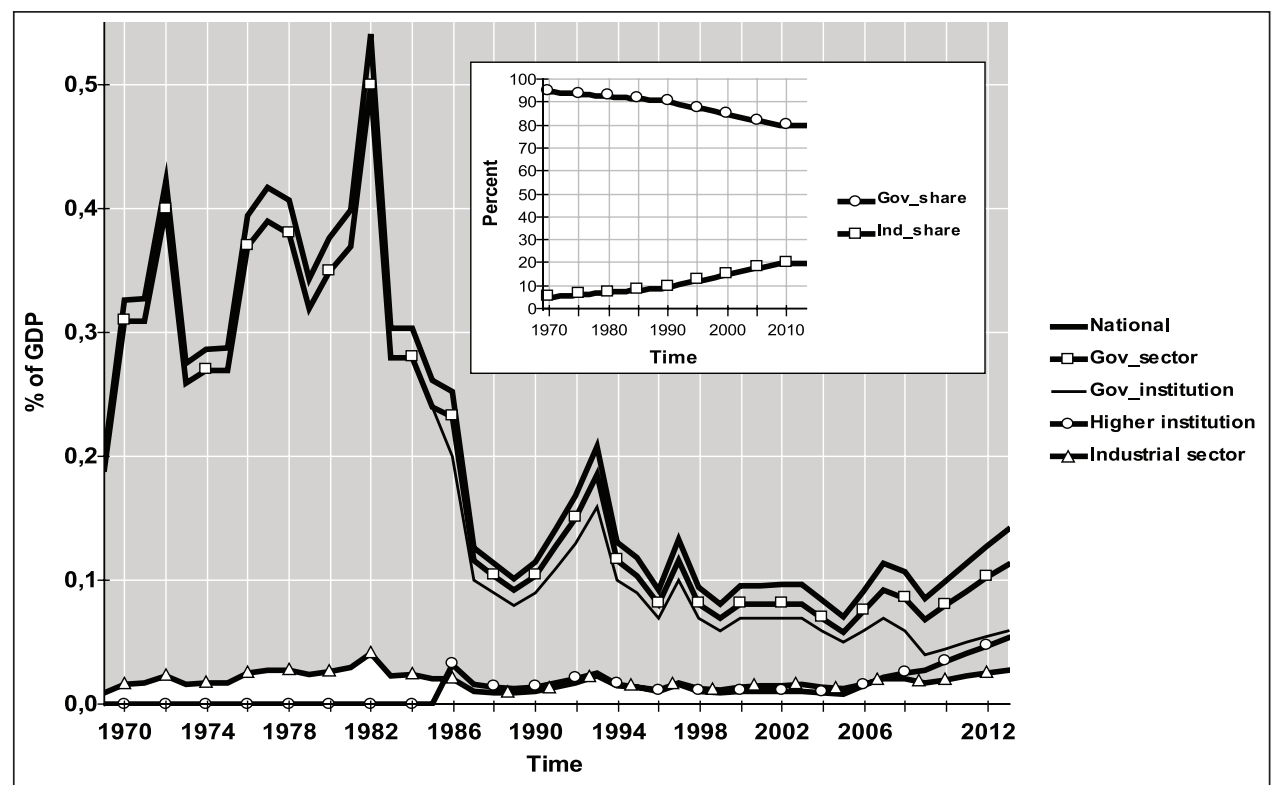

Source: Processed from Pappiptek-LIPI (2014), see also Aminullah (2015)

Figure 2. Trends of R\&D Intensity by Sectors (1970-2013)

There are three situations that related to low R\&D intensity in Indonesia. First, there are large portion of Low and Medium Technology (LMT) industry. The industry produces low technology products which do not require R\&D activities. Second, lack of government attention towards S\&T development has been getting worse since the 1990s. In the 1980s, S\&T budget was about $2.5 \%$ of total government budget. However, in the $1990 \mathrm{~s}$ it dropped to around $0.5 \%$, and then S\&T budget remained approximately $0.5 \%$ of total government budget in the 2000s. Third, share of private $R \& D$ intensity is very low because the private sector is generally less interested in reinvesting their production yields into $R \& D$ activity. Such a low R\&D intensity has kept Indonesia continue producing low-end products in the economy, as shown by the large portion LMT industry in the industrial sectors. In 2010, industrial R\&D expenditure was very small, only $0.013 \%$ of GDP or it was about US\$ 90 million of the Indonesian GDP, which amount to US\$ 700 billion (Aminullah, 2012, 2015).

\section{3) Low Scientific Publications and Patent}

Viewed from output indicators, publications and patents, Indonesia is far behind the neighboring countries such as Singapore, Malaysia and
Thailand. Among the ASEAN countries, Indonesia ranks fourth in terms of publications, and its position has been constant in the last fifteen years. While Malaysia, which ranks third in 2000s, has risen to the second place in 2010s. The rapid increase of Malaysia's scientific publications by 6 folds within 5 years (2006-2010) was due to the significant increase of R\&D intensity from $0.6 \%$ to $1.1 \%$ in the same period.

Furthermore, seen from patent granted in USPTO, Indonesia's position is almost non-existence with yearly patent granted less than 10 . In comparison, Malaysia has yearly patent granted around 200 and Singapore has even more, rising twice from 400 to 800 in the period 2008-2012. Seen from patent granted by Indonesian patent office at Directorate General of IPR, Ministry of Law and Human Rights, patent inventors are dominated by foreign inventors, while the role of domestic inventors is very small. The yearly granted patent for foreign inventors between 1,000-2,500, while for Indonesian inventors around 100-200 patents per year (see Figure 3).

\section{4). The Dominant Role of Innovation without Formal R\&D}

Based on the data of Indonesian innovation survey 2011, $61 \%$ of industries engaged in 


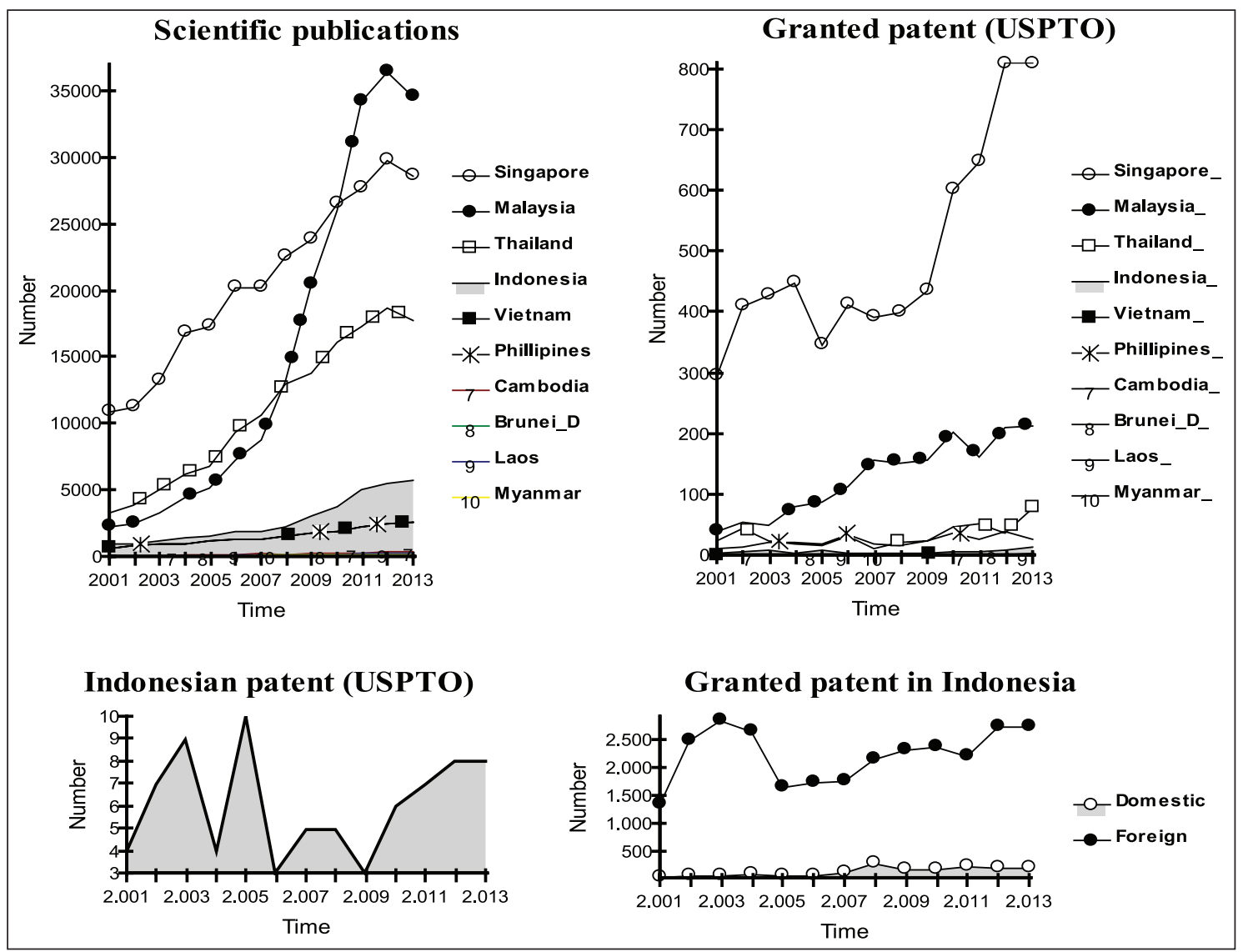

Source: Pappiptek-LIPI (2014)

Figure 3. Trends of Scientific Publication and Patent (2001-2013)

product, process, organizational and marketing inovations. Among those innovative firms, around $52 \%$ of them inovated by not engaging formal R\&D activities. The firms innovate either through non-R\&D or informal R\&D innovations. The sources of information which were frequently used by industry to innovate are external sources (supplier, user/customer, and competitor), internal sources (marketing, production, management, business partners) and other sources such as internet and conferences. The role of R\&D unit is less influencial as a source of innovation for industry.

The similar patterns of dominant role of innovation without formal $\mathrm{R} \& \mathrm{D}$ also exist in machinery and food sectors. The machinery sector is more frequent in making use of external and internal sources of innovations as well as other sources such as internet and conferences. While the food sector is higher in utilizing institutional sources of innovation than machinery sector, such as private laboratory, university and government R\&D institution (see Figure 4).

Given these statistical evidences, the objective of this study is to obtain deep understanding on why and how firms could engage in innovation without formal R\&D, by conducting a case study on the selected firms from machinery and food processing sectors.

\section{B. Case Study Method}

The case study was done in order to have a comprehensive explanation behind the statistical evidence about innovation without formal R\&D. The stages of this case study were done as follows; i) Selection of three cases of innovative firms from manufacturing sector (machinery and food processing), firm A (boarding bridge product), firm $\mathrm{B}$ (noodle products), and firm $\mathrm{C}$ (seafood products); ii) Collection of existing information about firms from various sources (previous case studies, public documents and 


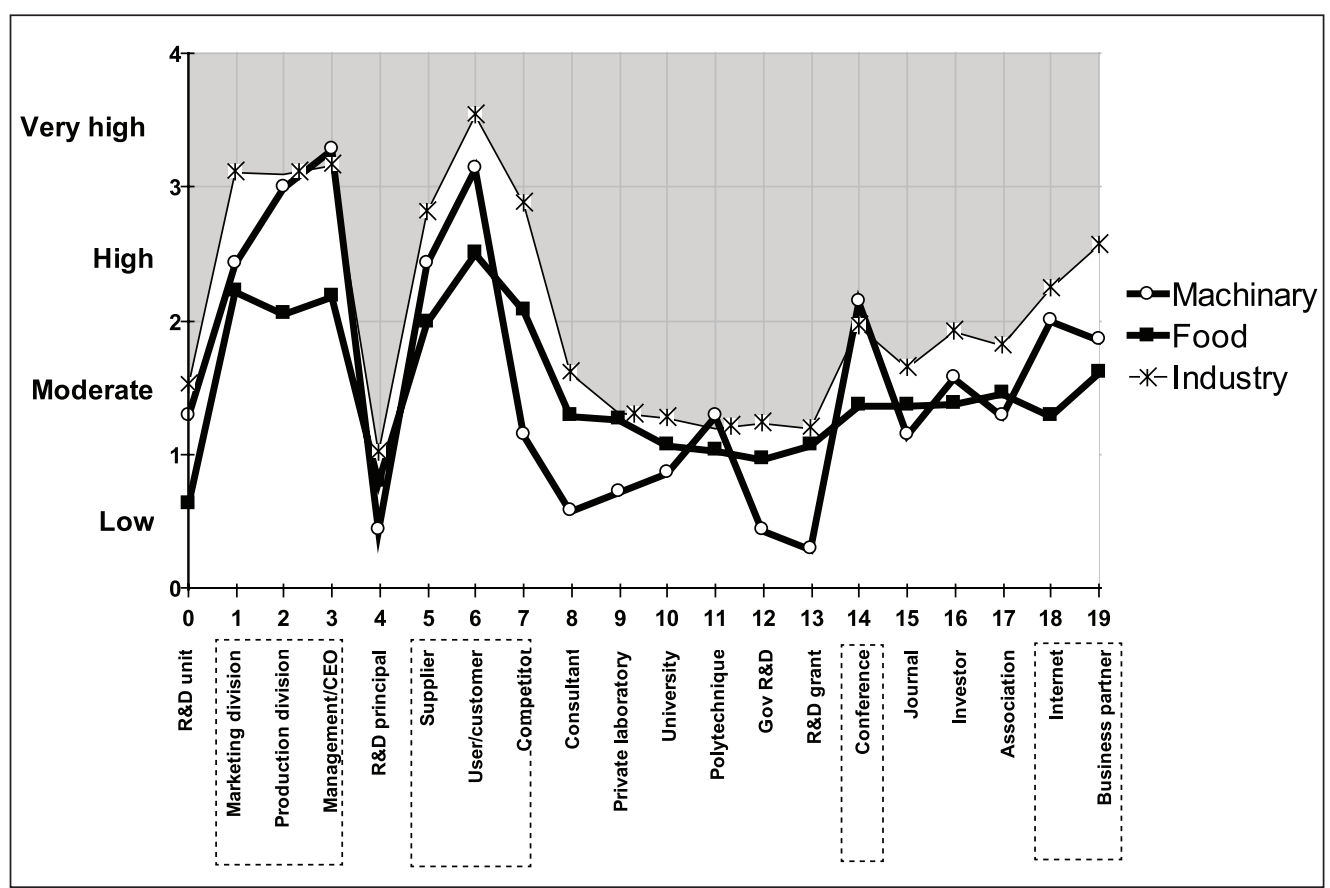

Source: Processed from Pappiptek-LIPI (2013)

Figure 4. Sources of Innovation in Indonesian Manufacturing Industry (2011)

literatures) then followed by further interviews to complement the existing information. Types of information collected covers business evolution, technological capability upgrading and drivers of innovation. Beside gathering new information through in-depth interview, some data for the three cases utilized previous case studies (Aminullah, Fizzanty, Kusnandar \& Wijayanti, 2013; Aminullah, 2014; Aminullah, 2015). It is important to note that making use of the same data for different purposes here by constructing totally different analytical framework will be explained in the next section; iii) Analysis by using analytical framework of innovation without formal $R \& D$ is directed to the type of innovation, sources of innovation, modes of innovation, and technological capability stages for each type of firms. By using cross cases analysis of three case studies, the comparative analysis was directed to explain why and how firm innovates without formal R\&D in upgrading technological capability and enhancing competitiveness; iv) Formulation of recommendations on how firms and policy makers should anticipate the future growth of firms, given the existing growth through innovation without formal R\&D. The findings could also contribute to enhancing knowledge on innovation policy in Low R\&D countries (LRDCs), especially Indonesia.

\section{ANALYTICAL FRAMEWORK OF INNOVATION WITHOUT FORMAL R\&D}

The creations of innovative products and processes as the result of $R \& D$ activities have been vastly documented in the body of literature. However, there are neglected facts that most innovative products and processes are contributed by the innovation activities without $R \& D$. With reference to Frascati Manual 2015 by OECD (2015), the nature of R\&D is always aimed at resulting new findings (novel) based on original concept (creative), it is largely uncertain about final outcomes (uncertain), it is planned for and budgeted (systematic), and it is aimed at producing results that could be accessed freely (transferable/or reproducible). Innovation activities that do not fulfil these criteria is called here as innovation without formal $R \& D$. The framework of analysis for innovation without formal R\&D will be described in the following section. 


\section{A. Innovation Based on R\&D Availability}

Viewed from R\&D availability in developing new products or processes, a firm has two options, either through formal or informal R\&D. The firm carries out a formal R\&D if they officially manage, allocate resources and direct the $R \& D$ activities to create new products or processes inside the R\&D unit. Firms that have formal R\&D can engage in in-house $R \& D$ or practice $R \& D$ out-sourcing. In contrast, the firms conducting informal R\&D when they unofficially manage, allocate resources and direct innovation activities to create new products or processes without having formal R\&D unit.

Firms that have informal R\&D can be distinguished from firms which do not have R\&D unit, or non-R\&D firms. Informal R\&D can be found occasionally in large firms, while non-R\&D are usually found in SMEs. Both firms with informal $R \& D$ and non-R\&D are firms that engage in innovation activities without $R \& D$, and generally can be found in Low and Medium-Tech (LMT) and Low-Tech (LT) firms. Graziadio and Zawislak (1997) found that informal R\&D activity is continuous, but it is driven by the need to solve the problem. Most of the new ideas are generated by blue-collar employees, using the creativity, experience and knowledge. Hervas-oliver, Garrigos, and Gil-Pechuan (2011) revealed that innovation can be explained by using non-R\&D variables such as marketing, design or hire employees in tertiary level work for explaining the innovation in products and processes.

\section{1) Types, Sources and Modes of Innovation}

The innovative learning produces certain types of product, process, organization, marketing, position and paradigm innovations. Product innovation is a change in the products and services offered; process innovation is a change in the way products and services created; organization innovation is a change in the ways products and services organized; marketing innovation is a change in the ways products and services marketed; position innovation is the change of the context of products and services framed; and the innovation paradigm is a fundamental change in the mental models of the products and services established (Bessant \& Tidd, 2007).

In managing innovation without formal $\mathrm{R} \& \mathrm{D}$, firms may use internal and external sources of innovation. Internal sources of innovation can be obtained from the problems/failures in the work found by the people (management and workers), appearing in the equipment, detected by the information system and occurs within the organization. External sources of innovation can be input/feedback coming from people (customers, suppliers, competitors), or learned from the development of science, technology, networks, institutions, markets and organizations outside the boundary of firm (Malerba, 2004). The ways in which firms engage in innovation can occur from the simple to complex modes, from learning by doing, using and interacting (DUI) moves towards learning by integrating and porting (IP), and then perform R\&D in the field of science, technology and innovation (STI). (Kodama, Nakata, \& Shibata, 2014). Finallly, viewed from the types of learning, it can be passive, active and proactive learnings. The description of innovation without formal R\&D can be viewed from different contexts (see Figure 5).

\section{2) Contextual Description of Innovation without Formal R\&D}

Viewed from technological capability level, firms move from operational capability to technical, design and engineering, and technology development capabilities. It reflects the movement of firms' activities that shift from technology use and operation, technology acquisition and assimilation, technology upgrading and reverse and engineering towards R\&D activity. The rise of this capabilities is in-line with the progress of low-tech (LT), low and medium-tech (LMT) and high-tech (HT) firms. Huang et al. (2011) categorized those firms innovate through in-house R\&D has a high innovative capability, while firms that only innovate through the adoption of innovation technology has a low innovative capability. Firms that have R\&D outsourcing and creative innovators with non-R\&D are assumed to have intermediate innovative capabilities. 


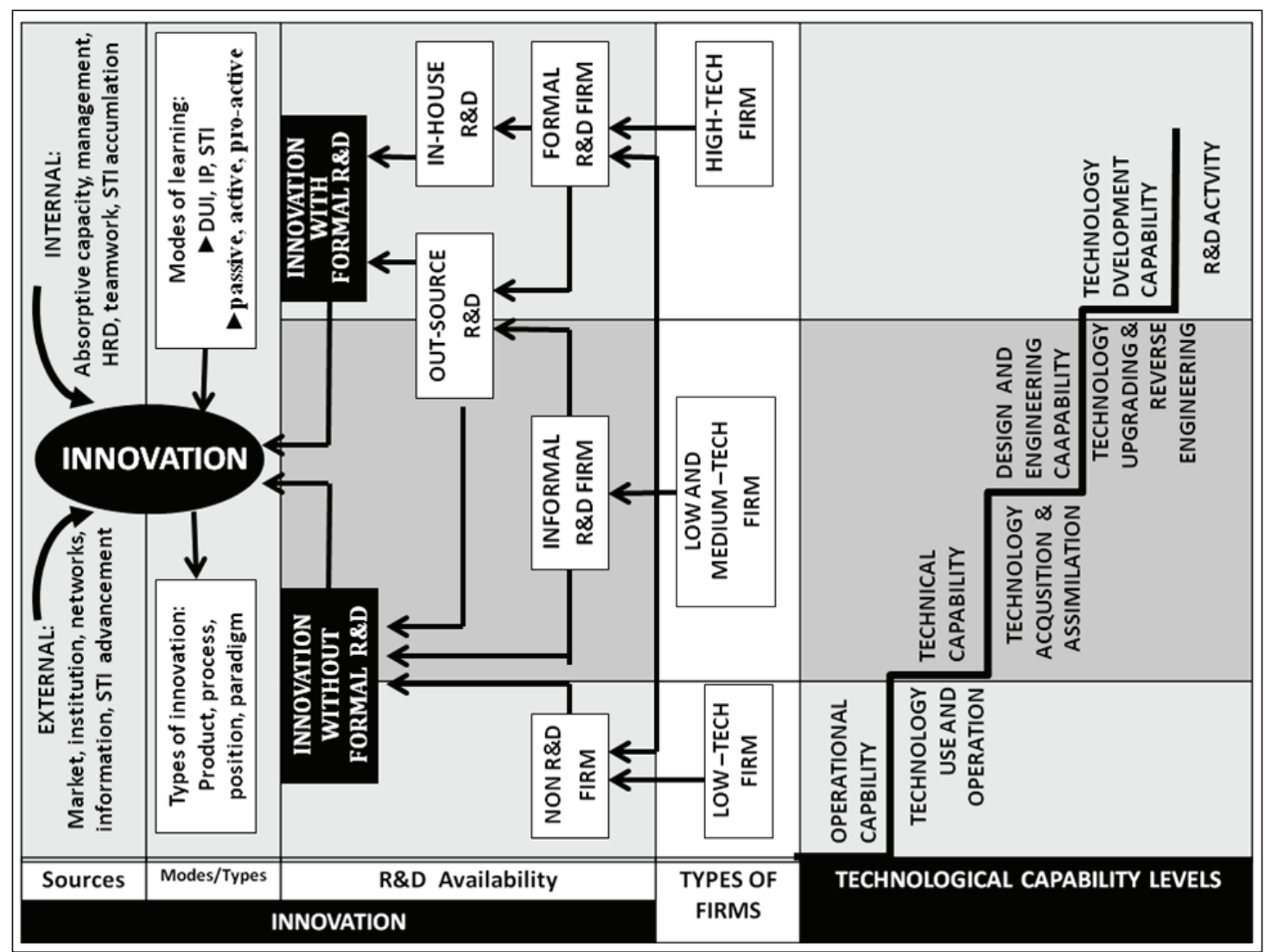

Source: constructed from Graziadio and Zawislak (1997); Hervas-oliver et al. (2011), Bessant and Tidd; (2007), Malerba (2004); and Kodama, Nakata, and Shibata (2014)

Figure 5. Analytical Framework of Innovation without Formal R\&D

Viewed from innovation management, innovation through informal R\&D involves the coordination of multiple processes and mechanisms, such as i) consultation, maintain informal contact and visiting clients, tool suppliers, equipment suppliers, material suppliers and other plants; ii) collecting information from sector guides, folders, specialized magazines, books; iii) using the ideas of those internal group meetings, the employee's own experience; iv) internal use such as manual paper, card manufacturing, shape, design, etc.; v) participate the meeting, association, sector events, exhibitions (national and international); vi) engineering consulting firms, databases, experts and institutions; and vii) employ external advice and training support, such as a new service offered by universities (Graziadio \& Zawislak, 1997).

Furthermore, Cohn (2013) argued that there is a need to innovate innovation or to manage innovation beyond R\&D. Firms need to develop a culture that supports innovation, which can have a greater impact on the outcome of the additional spending on the traditional R\&D. Hervas-Oliver,
Sempere-Ripoll, Boronat-Moll and Rojas (2015) analyzed how management (organizational and marketing) of innovations affects the performance of non-R\&D innovators of technology. Non-R\&D innovators heavily use technology and marketing activities of the organization in order to compensate for the lack of involvement in R\&D activities. Rammer, Czarnitzki, and Spielkamp (2008) explains that SMEs with no in-house $R \& D$ can generate innovation if they succeeded in effectively implementing human resource management tools or teamwork to facilitate the innovation process, especially when combined with each other or in combination with the source of external knowledge or co-operation with external partners.

Innovation activities by non-R\&D firm was revealed by Santamaria, Nieto, and Barge-Gil (2009) that non-R\&D activities such as design, the use of advanced machinery and training are especially important to understanding the innovation process of LMT firms, particularly for the achievement of product innovations. Santamaria 
also suggested the importance of external sources of process innovation in LMT firms, such as the use of consultants, the hiring of personnel, collaboration agreements and external R\&D. Arundel, Bordoy, and Kanerva (2008) found that the most frequently cited source for non-R\&D performers, after management, is marketing, production engineers and design staff. Non-R\&D innovators innovate to adjust or modify the product, process, or organizational method developed by the firm or other organizations.

$R \& D$ outsourcing is important for the efficiency of R\&D activities, but not necessarily effective for R\&D productivity. The combinations of R\&D outsourcing at low levels with internal R\&D investments largely contribute to the performance of firms' technology innovation. Firms with internal R\&D at a low level of technological knowledge are not effective in integrating external innovation activities. Tsai and Wang (2009) and Kim and Lim (2015) found that there is a thresholds of R\&D cost that encourage firms to prefer having R\&D outsourcing through innovation contest. R\&D outsourcing become common practice in the industry such as medical devices and software developments. Rammer et al. (2008) describes that SMEs can contract out R\&D to reduce the risk and allow them to better control the cost of R\&D. However, focusing on finding external sources of innovation without in-house $R \& D$ is less successful strategies, such as occasional $R \& D$ (i.e. start $R \& D$ only in the case of technological problems need to be resolved).

The use of machines is important to understand the process of innovation (Santamaria et al., 2009). Innovations in production processes have significant impact on the performances of LMT firm (Robertson \& von-Tunzelmann, 2009). Meanwhile, placing higher emphasis on the quality of products and processing allows LT firms to differentiate themselves from global competitors through excellent product quality and reasonable cost of the process (Kirner, Kinkel, \& Jaeger 2009). Furthermore, Grimpe and Sofka (2009) found that the LMT firms investing in R\&D to develop absorptive capacity (AC) can achieve the highest results if they direct the innovation towards fulfilling customers' needs. Som, Kirner, and Jager (2013) found that the development of
AC plays a major role for non-R\&D-intensive firms because it allowed them to successfully manage and implement technology adoption.

\section{THE CASES OF INNOVATION WITHOUT FORMAL R\&D}

Three cases of innovative firms studied in this paper were manufacturing industries (machinery and food processing), namely Firm A (boarding bridge product), Firm B (noodle products) and Firm C (seafood products). The definition of "without formal R\&D" in this studies includes non-R\&D, informal R\&D, and outsourcing R\&D from informal $R \& D$. These categories cover the activities of innovation in developing product, process, organization, marketing, position and paradigm innovation. These activities of innovation are beyond the nature of $R \& D$, which is always science-based innovation, and thus which is aimed at new findings (novel) based on original concept (creative) that can be measured by the number of patents or scientific publications. The three firms have no patents and/or scientific publications.

\section{A. Case of Firm A (Machinery Product)}

\section{1) Business Evolution}

Firm A engages in the field of engineering, procurement and construction. The firm was initially started the business in the field of small-scale workshop in 1978. The outset firm's management has realized that the ability to innovate, to compete and competitiveness is the main assets of survival in the global competition. The firm has a great vision to be a leading Indonesian company in engineering, procurement, construction, and even energy investment in the world. The firm conserves its corporate values of integrity, teamwork, professionalism, innovation, excellence.

The firm had rapidly transformed its business from motor vehicle workshop to integrate steelbased engineering and energy. In the period of 1990-2000, the firm began introducing an array of new products, including boarding bridge, steel bridge, steam power plant, power transmission, and oil and gas projects. In that period, the firm listed in the Indonesian Stock Exchange and 
also obtained certification from ISO, as well as certification from the American Petroleum Institute (API) for oil and gas related services. In the period of 2000-2010, the firm obtained the certificate of Quality Assurance and OHSAS, and started the construction of Hydroelectric Power Plant (HEPP). In 2013, the firm expanded the business into hydroelectric power distribution as well as operating and consultation for hydropower. Furhermore, in 2014 the firm began acquiring several companies in the field of mini hydro power plants.

The firm produces variety of products: power generation, galvanize, road construction equipment, oil \& gas equipment, special purpose vehicle, steel tower, steel bridge and boarding bridge - the latter is one of the firm's main product. The firm produces two types of boarding bridges, steel and glass wall. These products have been exported to many countries, such as Japan, Thailand, Hong Kong, China, India, Malaysia, Chile, Bangladesh, Myanmar, Brunei and Singapore.

\section{2) Types of Innovation}

Product innovation. The firm develops products or engaging in product development that is organized by production division. The firm carries out product development based on the problems encountered when the firm makes a big project. Although the firm does not have formal R\&D unit, it still has laboratories to carry out product testing or measurement of a certain technical parameters. The firm engages in product innovation by pursuing three modes of technology upgrading: i) modified existing technology, ii) learning by doing, and iii) mastering from using.

i) Modified existing technology. The firm engages in incremental innovations by creatively imitating the existing technology or existing product and follows the required standards by home country or abroad. Since the technologies are already well-established, and have basic standards and accessible to the public - such as hydropower technology, boarding bridge, steel bridge and so on - the firm has no longer need doing the formal R\&D. The firm only needs doing reverse engineering from the existing product or design, then modifying the design to develop a new product, all of which can be done without formal R\&D. Although the firm follows the standards of technologies that already exist, the firm also adds some values to the technologies by modifying the design, up-scaling the existing design and the efficiency of the products, hence the products has distinctive features in order to compete with competitors. For instance, the firm has developed the boarding bridge made from steel walls into a glass walls design.

ii) Learning by doing. The firm develops its own product technology through learning by doing. The firm creates it by taking the financial cost of trying unfamiliar competence. i.e hydropower turbine technology. Initially, the firm has no experience on how to create hydropower technology in terms of detailed technical aspects. Learning is done by conducting some visits at the site of existing hydropower, then observing the making of technical drawings in hydropower. The operators and engineers who work in the existing hydropower train the firm's engineers on the system design and engineering of hydropower in details. If the knowledge of firm's engineers is still lacking, the top management will call experts from domestic or abroad to give lectures related to the mastery of technologies that are not fully understood. When all the needed information has been obtained to develop the product, then the firm's engineers will perform product designing and testing before producing it for domestic market, which has been secured first by marketing division.

iii) Mastering from using. The firm also developes new products after mastering the use of technology bought from technology supplier, without doing formal R\&D. The mastering from using emphasizes that the firm does not want to heavily depend on foreign technology supplier in terms of spare parts, installation technology and software embodied in these technologies. In buying a product from a particular manufacturer of technology, the firm requires the supplier 
to provide overall technical drawings and manuals, the firm does not expect technical assistance and installation process operator, and the firm also does not expect any warranties. Given such pressures, engineers inside the firm will engage in total learning by using the technology that has been purchased. The engineers sometimes created the firm's own software to run the technology system and made the necessary spare parts in anticipating any possible damage in the future.

Process innovation. The firm's management views that reaching maximum effciency in the production process through automation is a must, if it is supposed to survive in global competition. Parallel with automation that is now being underway, the firm is also pursuing to increase its quality of human resources by providing regular training. Currently, around $30 \%$ of the firm's 900 employees hold bachelor degree, mostly in engineering science. It allocates some funding for its staffs to attend formal degree education and in-house training. HRD policies have targeted that $20 \%$ of employees' time is to take training courses. Beside the technical training program, the firm also provides training related to knowledge management in order to organize existing knowledge to be recorded as explicit knowledge and to facilitate easier knowledge transfer. Due to the nature of the firm's knowledge that is tacit and owned by engineers, the need for knowledge management is necessary for the firm.

\section{3) Sources of Innovation}

Customer needs. The firm regards the customers as a source of innovative ideas to keep innovating. The firm strives to provide products that match the needs of customer; the example is the firm's move to develop the boarding bridge made of glass. The initial idea is based on customers' demand to replace the steel used in boarding bridge with glass. The customers get the idea after seeing a glass-made boarding bridge in other countries. In respond to that, the firm has to redesign the steel boarding bridge and replaces the main material with glass to match the demand.

Knowledge surveillance. The firm actively conducts 'knowledge surveillance' to closely watch and learn by seeing similar innovation that has been done by other companies or competitors. The firm's management believes that making something does not need to start from basic; it could be done creatively and quickly with breakthrough. Interactive learning from consultants is another source of creative ideas for the firm, especially the idea of solving the firm's problem in product development. Also, the firm sents staffs to attend workshops abroad for two main reasons. First, it can provide inspiration about the picture of latest technological advancement; second, it creates new opportunities. Existing documents on detailed design and engineering available at the market could be other source of innovative ideas. For example, the firm's successful turbines production is due to its ability to imitate the knowledge gained after meeting with the producer of turbine in Prague and Germany.

Market competition. Tight competition particularly comes from significant progress of industry in China that drives many firms to continue engaging in innovation. Firm A creates new product development using certain technologies by financing the cost of learning in developing the product. The firm has developed the competitive hydropower turbin technology. The firm's competitiveness can also be seen from its capability in developing other products such as passenger boarding bridge. This product has been exported to many countries, showing the firm's ability to penetrate global markets. As for the product competitiveness, those boarding bridges are priced well and have better quality than that of similar products from competitors. In order to maintain its competitiveness, the firm continues to keep a close watch on its competitors, so that the firm can identify the opportunities to get better than its competitors.

Interactive learning. The process of learning is also applied by interacting among staffs to make up for the lack of knowledge. The firm's management has practiced the principle of "the needed knowledge was actually available and it was just not yet collected". The firm continues to actively conduct searching and acquiring the important (including tacit) knowledge through various activities, including experts visitation who are paid in high price. The experts are 
asked to share their knowledge to the group of engineers inside the firm. The learning process occurs through such interaction between experts and employees. Furthermore, the firm conducts knowledge comparison by searching and learning to other countries such as China, India and Bulgaria. Based on comparative analysis, gained knowledge is codified in the form of drawing the design. In order to make improvements, the drawing is then reviewed by inviting Chinese consultants to determine the possible errors in the drawing. After the drawing is fixed, the firm hires another consultant to re-check it. Therefore, the firm has been able to create new products through actively conducted searching and interactive learning activities.

\section{4) Case of Firm B (Food Processing Product)}

\section{a. Business Evolution}

Firm B has been established since 1990 and the main business is food processing. The firm's business ranges from cultivation to distribution and consumers products. Its business also has transformed from production and processing of raw material to consumer food products, in which innovation is its major strategy. The food business is promising and sales have reached USD 5 billion or 63.6 trillion IDR in 2014. Firm B has been registered as public company at Indonesian Stock Exchange Market since 1994.

Noodles division within the branded consumer products will be the main focus. Its production capacity reaches 16 billion packs a year with various noodle products and covering various market segments. The firm has achieved numerous awards in consumer branded products noodles by several domestic institutions in terms of its brand, marketing and consumer's satisfaction. All of these achievements have positioned this company as a producer and market leader in Indonesia and acknowledged as one of the biggest noodle producers in the world. The company has strong commitment to its consumers by ensuring highly products quality and product taste acceptance.

The global expansion process in noodles division began in 1996 as a new subsidiary in Nigeria — one of African most promising markets.
In only five years, in 2001 to be precise, the firm expanded its factory in Nigeria. This success has motivated the company to also expand its business in Asian countries through acquisition and joint venture strategies. The firm acquisited Malaysian noodle factory in 2006 and Syrian noodle factory in the following year. The rapid growth of its factory has driven Firm B to apply automation process in its production in 2012, or 15 years after its first expansion in this country.

\section{b. Types of Innovation}

Firm B engages in three types of innovation: i) management innovation by establishing the standardised management system in every countries; ii) product innovation by developing new product regularly and developing new noodle flavours from recipe contest; iii) position innovation by changing the context of products framed from instant food producer and shifting to be a part of food nutrition producer.

Management innovation. The firm has set up standardised management system for its local partners in each countries, following international standard such as HACCP and ISO. All business partners have opportunity to attend training program. Management training is provided at head-quarter office, while technical training is provided as a part of the job training aiming to develop capacity of local partners to follow certain standards. There are some standards to follow, such as production machines, production process, quality control and consumer's standard. In order to ensure the standard management worked properly in a new subsidiary company, the firm will assign a key manager from headquarter to work in that country.

Product innovation. Every year, the firm launches three to four new products in order to secure brand loyalty of consumers and also to meet various market niches. Continuous innovation is a competitive strategy for the firm through research funding support and recipe contest. This open innovation has created opportunity for the firm to upgrade its capability and also makes the innovation process more efficient. All testing process is conducted internally as it owns laboratory and facility to ensure that new products can meet 
various standards. The firm employs five staffs from food technology and food analysts in new product development division. The firm set up target to this division to develop new products every year and store them in new products 'bank'. The marketing will examine which products are going to launch next year after carefully testing it on market.

Position innovation. The firm has secured the position as instant food producer and shifting to be a part of food nutrition producer especially for young generation. Considering health issue, the firm just launched healthier noodle with adding fibres and vitamins into it, such as salmon teriyaki flavour, seaweed flavour and pizza cheese flavour, just to name a few. The new innovation is expected to penetrate new market, for example, noodle for kids' nutrition. A growing market of instant noodle has changed Indonesian eating habit, from slow cook food to instant food, as noodle is identical with more practical life style.

\section{c. Sources of Innovation}

Market/user needs. Developing the existing products and creating new products are types of innovation conducted by Firm B. New knowledge for product development comes from responding to users' needs. Knowledge from users are collected and channeled from marketing division to product development division. New product development is a regular activities conducted by local staffs which produce variant tastes of product. The firm also makes use of food contest as innovation outsourcing to collect and select the best cuisine from community creation in cooking the noodles. Series of testing, such as consumers testing and product testing, are conducted before the firm launches a new product. The firm promotes innovation through passive learning that is dominated through stadardized internal processes and innovation outsourcing.

The firm maintains continuous product innovation under the growing global market demand especially in Asian and African countries. Meeting the food demand for market in developing countries has contributed for the firm's expansion in these regions, as well as the availability of creative community in introducing traditional cuisine recipes into modern noodle production which has driven the firm to innovate. The firm invested in production capabilities in the existing machinery by hiring local engineers with capabilities as food technologist and food analyst. The firm set up output target for the engineers in new product development. The engineers conduct some testings on various tastes and product appearance considering consumers' preferences.

Business risks and market competition. The standardized management system is driven by managing business risks and market competition. Managing business risks is the top priority of the firm's management, such as securing raw materials, market distribution and food security. The noodles business has developed strong partnership with suppliers in order to secure raw materials for this firm and has utilized its own group's distribution to ensure its products available in the market properly. Furthermore, the market competition is sensitive issue of ensuring raw material, price fluctuation, customers brand loyalty, competitors and achieving food standard. The most challenging issue in market competition is maintaning the quality of food standard. The management established customers service to obtain feedback from consumers, hence the firm is able to handle the food security issues rapidly.

Unique Indonesian cuisines recipes. Diverse ranges of taste in noodles are available in order to meet the market demand. Continuous product innovation has carried out firm to grow in the competitive market. The firm has succeeded to promote Indonesian famous and diverse traditional cuisines. The unique Indonesian cuisine recipes have inspired the firm to keep the Indonesian traditional cuisine as branding for its noodle. New tastes of noodles are launched every year to maintain customer loyalty to the product. The demand of Indonesian noodle in other countries, particularly in Africa, is different from other continent, such as in the size of noodle pack. The firm has taken the consumers acceptance into consideration, due to bigger size noodle which is more acceptable for African consumers, thus the factory in Africa produces bigger size noodle pack.

Promoting outsourcing research. It is a part of human resource capability program, not related to formal R\&D unit. Since 1998, the firm initiated 
a specific program called research funding program. In the beginning, the program focused on research output contest on wheat and flour. The scholarship program aims to assist undergraduate students or bachelor degree in completing his/her research thesis. The scholarship is announced to public annually, mainly in relation to food quality improvement and food diversification. All research proposals will be reviewed by board of experts in technology and food industries from national universities. The successful candidates will obtain support for research funding for maximum one year. Since 1998 untill now, more than one hundred research proposals have been funded. The research outputs focused on food diversification including socio-economic issues, which can be a source for the firm to support continuous innovation in its business.

\section{5) Case of Firm C (Seafood Prosessing Product)}

\section{a. Business Evolution}

Firm C is located in Jakarta's marine industrial complex and established in 1999. The firm is one of the leading fresh frozen tuna producers in Indonesia and employs over 400 workers. The firm produces various fresh and frozen fish products, of which mostly are being distributed for export markets.

The founder of the firms started as a small fish traders in Eastern Indonesia Region in early 1990s. The founder, as an owner, entered shrimp trading in collaboration with the fishermen from similar region in the period of 1995-1996. The firm managed the inter-lock collaboration with local fisherman, the so-called "plasma nucleus system" to secure its fish supply. In 1996, the firm shifted its focus to tuna processing in order to handle high competition and unstable supply, but the firm failed to address the similar problem of unstable supply that continued to re-occur afterward.

The recurring events taught a lesson for the firm to not depend on one commodity, but to expand to various seafood commodities and diversify the business by the end of 1996. In 1999, the firm built cold storage as well as bought fish vessels and transporter vessels to support its business. In order to secure plant and storage for optimum operation under the lack of supply, the firm imported raw fishes. Currently, the firm is the largest Indonesian importer of salmon from Norway. Since 2011, the firm has also become a food logistics company that provides modern logistic services, including re-packing, labelling, cargo service and port documents. The uncertainty of raw material from local supplier motivates them to diversify its business into logistic service provider.

\section{b. Types of Innovation}

Product innovation. Product diversification and creating new market is the firm's strategy to minimize risk of unstable supply of tuna. The firm obtained knowledge for establishing new product development by interacting with its international buyers through the director, marketing and production staffs. The market trend has influenced the firm to evaluate its products continuously. Information feedback from foreign retailer, global importer, machinery and equipments supplier has influenced the market trends.

Process innovation. Firm $\mathrm{C}$ begins its operation using a conventional cold storage, but then continuously upgrades its processing technology after learning by interacting with technology suppliers. Subsequently, the firm has advanced warehouse system by using robotic technology (automatic and computerization). The firm upgrades its fish processing with the most efficient technology in space, labor and energy uses. The firm has the first cold storage company in Indonesia that uses automated storage/retrieval system [AS/RS] in its warehouse system. The use of modern technology, such as food storage and processing and logistics technology support, makes the firm to be responsive towards market/ user needs. Innovation in logistics such as cold storage, automated storage, advanced processing and packaging, and cold chains has reduced cost of logistic and raw material processing.

Management innovation. The firm applies its own production management system to meet the global standard of food safety and production standard. It sets up modified system, which is derived from other system, for example, 
evaluating Indonesian manual production system with Chinese, Thai, and Vietnamese system, their combination with European automated system to improve the speed of production. The efficient production management system includes raw material diversification, imported raw material, plants establishment near raw material supply and uses logistics automation. Such market factors (competition), technology (the ICT access and logistics technology) and networks (raw material supply chains) have induced the firm's cost cutting innovation.

Another kind of managemet innovation is a marketing innovation that had been done by firm through managing partnership along the fish commodity chains. High competition between fish processing companies has driven the firm to work closely with suppliers through supply chain management or through interlock collaboration under loose relationship. Managing a good partnership is an important strategy for the firm to ensure their suppliers committed to supply them continuously. The firm invests in its partnerships in terms of ice supply and training on production quality for the fish suppliers.

Organization innovation. The firm always faces intense competition in securing raw material for its processing centers. Moreover, it has to deal with the cost inefficiency due to seasonal supply of raw material available for processing centers, high risk transportation mode particularly from suppliers to the processing centers, and an increase of labor cost. These business pressures make the firm can not fully operated due to difficulty in maintaining supply of raw material, hence the firm decides to shift a part of its business organization to be food logistics for other products instead of seafood.

\section{c. Sources of Innovation}

Business partner. Visiting abroad after searching information from internet and interacting with technology suppliers are major sources for the firm to explore business opportunities and upgrade production process, product diversification, and its managerial capability. The firm owner, also as the director, has long experience working in fishery industry and foreign vessels companies and has good networks with government and business both domestic and abroad. These advantages help him to see business opportunity, such as becoming the biggest salmon importer in Indonesia for export market. The firm reduces production cost by establishing close networks with local and international suppliers or even with competitors or seafood international business networks. The strong business networks have opened opportunity for firm to learn new production process.

Internal actors. Management (director) and skilled production staffs are the important assets for coming up with innovative ideas for firm's survival. The director has an idea of diversifying its business in terms of fish variety, produces new products and transforms its business from fish processing towards fish logistic service for firm's survival in the era of uncertainty.

Market/user needs. Most of the firm's products development and diversification are based on information feedback from users. The firm develops its own brand to support its market position and differentiation in the world market. The firm has to meet the quality and safety standards to be accepted by market/user. The way of users involved in product development and diversification could be direct or indirect. The users' direct involvement occurs in the process of products testing, while indirect involvement occurrs in collecting market information by interacting with wholesalers, global retailers, marketing department or by his own/entrepreneurs observation.

Technology supplier. Logistic innovation either by expanding and/or applying more advanced technology has reduced the problem of seasonal supply and secured the quality of fish products. The source of logistic innovation is information availability from technology suppliers. The availability of logistics technology infomation inspires the firm to innovate in delivery service for customer. The demand of delivery service is also high due to market competition. The utilization of logistics technology for delivery service has compensated the reduction of firm's production capacity. Besides, the firm's business networks has contributed to expand into the logistics service. 


\section{DRIVERS OF INNOVATION WITHOUT FORMAL R\&D: CROSS CASES ANALYSIS}

Each firm producing different products through different ways of technological capability building engages in innovation without formal R\&D. Firm A produces machinery equipments by using its own design and engineering capabilities, that has been build through active learning process. Firm $B$ produces food products by utilizing the uniqueness of Indonesian cuisines using standardized system and advanced machinery equipments. Firm $\mathrm{C}$ produces seafood products by operating automation equipments in seafood processing. In terms of technological capability levels, Firm A has succeeded in achieving the level of technology upgrading and reverse engineering through informal R\&D, whereas Firm B has maintained the level of technology aquisition and assimilation through informal R\&D, and Firm $\mathrm{C}$ has attempted the level of technology use and operation through non-R\&D.

Seen from types of innovation, each case of firms generally conducts product innovation and process innovation. Firm A produces design and engineering products by modifying existing technology, learning by doing, and mastering by using. Firm B produces food products by developing new flavour based on traditional Indone- sian cuisine. Firm $\mathrm{C}$ produces food products by operating modern processing plant and automated storage/retrieval system (AS/RS). Each case has specific ways of conducting innovation according to its types of innovation. Firm A has performed to create machinary product through "mastering by using" based on the spirit of technology mastery by firm's own capability. Firm B has performed to bring a shift in people's food habit through MNEs based on the idea of bringing the Indonesian cuisine to global consumer. Firm $\mathrm{C}$ has performed to extend organization from food processing to logistic service by utilizing IT for higher business efficiency.

In realizing each types of innovations, all firms utilize both internal and external sources of innovation. The frequent use of external sources of innovation are market/user needs then followed by market competition/competitor. Each case has specific sources of innovations in building technological capabilities. Firm A developes its own capability through technological surveillance and interactive learning. Firm B brings the Indonesian cuisine to global consumer through its own laboratory and contest of traditional Indonesian recipes. Firm $\mathrm{C}$ operates modern processing plant and AR/RS after learning from business partner abroad (see Table 1).

Tabel 1.

Drivers of Innovation without Formal R\&D

\begin{tabular}{|c|c|c|c|c|c|c|c|}
\hline \multirow{2}{*}{\multicolumn{2}{|c|}{ Firms }} & \multirow[t]{2}{*}{ Areas } & \multirow{2}{*}{$\begin{array}{l}\text { Technology } \\
\text { types }\end{array}$} & \multirow[t]{2}{*}{ Technology levels } & \multicolumn{3}{|c|}{ Innovation } \\
\hline & & & & & Types & Sources & Drivers \\
\hline & A & Machinery & $\begin{array}{l}\text { Medium-tech } \\
\text { with automation } \\
\text { support } \\
\text { (underway) }\end{array}$ & $\begin{array}{l}\text { Technology } \\
\text { upgrading \& } \\
\text { Reverse } \\
\text { engineering }\end{array}$ & $\begin{array}{l}\text { - Product } \\
\text {-Modified existing } \\
\text { tech } \\
\text {-Learning by doing } \\
\text {-Mastering by using } \\
\text { - Process }\end{array}$ & $\begin{array}{l}\text { - Market/user needs } \\
\text { - Technology } \\
\text { surveilance } \\
\text { - Market competition } \\
\text {-Interactive learning }\end{array}$ & $\begin{array}{l}\text { Management } \\
\text { Vision and leadership }\end{array}$ \\
\hline & B & $\begin{array}{l}\text { Food } \\
\text { processing }\end{array}$ & $\begin{array}{l}\text { Low tech } \\
\text { with advance } \\
\text { machinery } \\
\text { support }\end{array}$ & $\begin{array}{l}\text { Technology } \\
\text { aquisition } \\
\text { and assimilation }\end{array}$ & $\begin{array}{l}\text {-Product } \\
\text { - Management } \\
\text {-Position }\end{array}$ & $\begin{array}{l}\text { - Market/user needs } \\
\text { - Business risk/ } \\
\text { competitor } \\
\text { - Traditional } \\
\text { Indonesian recipes } \\
\text { - Outsourcing } \\
\text { research }\end{array}$ & $\begin{array}{l}\text { Integrated business } \\
\text { system }\end{array}$ \\
\hline & C & $\begin{array}{l}\text { Fish } \\
\text { procssing }\end{array}$ & $\begin{array}{l}\text { Low tech with } \\
\text { automation } \\
\text { support }\end{array}$ & $\begin{array}{l}\text { Technology use } \\
\text { and operation }\end{array}$ & $\begin{array}{l}\text { - Product } \\
\text { - Process } \\
\text { - Management } \\
\text { - Organization }\end{array}$ & $\begin{array}{l}\text { - Business partner } \\
\text {-Internal actors } \\
\text { - Market/user needs }\end{array}$ & $\begin{array}{l}\text { Enterpreneurship } \\
\text { and networking }\end{array}$ \\
\hline
\end{tabular}


The variety of firms reflects different areas of businesses, different fields of technologies and distinctive level of technology capabilities. Each firm also shows specific type of innovation and specific source of innovation. This case study reveals that types and sources of innovation vary according to business areas, technology field, and capability level of each firms. In other words, each firm innovates through its own ways and it is driven by firm's unique resources. Firm A innovates to create its own design and engineering products driven by management vision and leadership. Firm B innovates to develop and contest the traditional food recipes driven by integrated business system. Firm $\mathrm{C}$ innovates to operates modern processing plant and automated storage/ retrieval system driven by entrepreneurship and networking.

Innovation without formal $\mathrm{R} \& \mathrm{D}$ will produce high results if the innovation is driven by firm's specific resources namely management vision and leadership, integrated business system, and entrepreneurship and networking. However, the studies from Grimpe and Sofka (2009) and Som et al. (2013) found that the LMT firms invest in R\&D to develop absorptive capacity (AC) can achieve maximum results if they direct the innovation towards fulfilling customers' needs, and the development of AC plays a major role for successfully manage and implement technology adoption. It is because innovation without formal $R \& D$ is deficient in $A C$; it implies that non- $R \& D$ and informal R\&D firms should invest in R\&D to develop AC and increases technology adoption.

\section{CONCLUSION AND POLICY IMPLICATIONS}

Firms manage innovation without doing formal $R \& D$ through various types of learning: i) passive learning, new knowledge from user response, product contest, and product testing; ii) active learning, new knowledge from interaction with shelfs of documents, invited experts, cross functional team; iii) proactive learning, new knowledge from the vision of top management to create a new product.

The reasons firms conduct innovation without doing formal R\&D are i) low technology of consumer products, only need to invest in the quality assurance of standardized products variants as well as modern IT based production system; ii) standardized products from existing machinery technology only need to invest in the designing capability for creating best quality product by using competitively local engineers.

Innovation without formal $R \& D$ produces innovative results driven by firm's unique resources, they are management vision and leadership, integrated business system, and entrepreneurship and networking. The conceptual contribution of this study is an enrichment to "learning by using" with a new variant the so called "mastering by using". The mastering by using is to create big solution by correcting the overall systemic failures through learning from using the system in work place. It is different from incremental/ continous improvement to solve a series of small failures through learning by doing in work place.

Innovation without formal $R \& D$ is deficient in absorptive capacity (AC), it implies that non-R\&D and informal $R \& D$ industries should invest in R\&D to develop AC and increase technology adoption. It is therefore, government policy by using $R \& D$ financing support and tax incentives should be directed to the innovative LT and LMT industries, which will have produce higher results through innovation with informal and/or non R\&D activities.

\section{Note:}

This article orginated from authors contribution in an unpublished research report by Patarapong Intarakumnerd (ed.) titled Industrial Development Along the Global Supply Chain, Organizational Evidences From Southeast Asia: How Firms Have Achieved Product and Process Innovations without Formal R\&D Unit or Personnel (Tokyo: ERIA Research Report 2015, pp. 5-81). Authors' gratefulnes extend to ERIA in supporting this case study based on ERIA's grant research project, 2015. 


\section{REFERENCE}

Aminullah, E. (2012). Coping with low R\&D intensity in Indonesia: Policy insight from system dynamic model. Journal of S\&T Policy and $R \& D$ Management, $10(1), 1-10$.

Aminullah, E. (2014). How capital goods firms upgrade innovation capacity: A case study. Journal of S\&T Policy and R\&D Managment,12(2), 85-97.

Aminullah, E. (2015). Learning, R\&D intensity and economic prosperity in low $R \& D$ countries (LRDCs): Envisioning the Indonesian future. Paper presented in Asialics 2015 Conference, Yogyakarta, November 15-17.

Aminullah, E, Fizzanty, T., Kusnandar \& Wijayanti, R. (2013). Technology transfer through OFDI: The case of Indonesian natural resource based MNEs. Asian Journal of Technology Innovation, 21(sup1), 104-118.

Arundel, A., \& Hollanders, H. (2011). How firms innovate: $R \& D$, non-R\&D, and technology adoption. Paper presented at the DIME Final Conference, 6-8 April, Maastricht.

Arundel, A., Bordoy, C., \& Kanerva, M. (2008). Neglected innovators: How do innovative firms that do not perform $R \& D$ innovate? (Working paper, results of an analysis of the Innobarometer 2007 Survey No. 215). Retrieved from http:/digitalarchive.maastrichtuniversity.nl/ fedora/get/guid:413b75a4-8774-4fa2-80ee$51 \mathrm{e} 8 \mathrm{~d} 357 \mathrm{~d} 117 /$ ASSET1

Bessant, J., \& Tidd, J. (2007). Innovation and entrepreneurship. Chichester: John Wiley.

Cohn, S. (2013). Enhancing competitive position through innovation beyond $R \& D$. Retrieved from https://timreview.ca/article/686

Graziadio, T. \& Zawislak, P. A. (1997). The role of informal R\&D activities in the evaluation of the SMEs technological capability: The mechanics industry in Brazil. In Jay F. N. \& Ralph H. S. (Eds.), Proceedings of the Thirtieth Annual Hawaii International Conference on System Sciences (518-527). California: IEEE

Grimpe, C., \& Sofka, W. (2009). Search patterns and absorptive capacity: Low- and high-technology sectors in European countries. Research Policy, 38 495-506.

Hirsch-Kreinsen, H. \& Jacobson, D, (2008). The low-tech issue. In H. Hirsch-Kreinsen \& D. Jacobson (Eds.), Innovation in low-tech firms and industries (3-22). Cheltenham: Edward Elgar.
Hervas-Oliver, J. L., Garrigos, J. A., \& Gil-Pechuan, I. (2011). Making sense of innovation by R\&D and non-R\&D innovators in low technology contexts: A forgotten lesson for policymakers. Technovation, 31, 427-446.

Hervas-Oliver, J. L., Sempere-Ripoll, F., BoronatMoll, C., \& Rojas, R. (2015). Technological innovation without R\&D: Unfolding the extra gains of management innovations on technological performance. Technology Analysis \& Strategic Management, 27(1), 19-38.

Huang, C., Arundel, A., \& Hollanders, H. (2011). How firms innovate: $R \& D$, non- $R \& D$, and technology adoption. Paper presented at the DIME Final Conference, 6-8 April, Maastricht.

Kirner, E., Kinkel, S. \& Jaeger, A. (2009). Innovation paths and the innovation performance of low-technology firms - An empirical analysis of German industry. Research Policy, 38, 447-458.

Kim, K-K. \& Lim, M.K. (2015 ). R\&D outsourcing in an innovation-driven supply chain. Operations Research Letters, 43, 20-25.

Kodama, F., Nakata, Y., \& Shibata, T. (2014). Beyond learning by doing: Behind global shift in echnological leadership. Paper presented at Asialics 2014 Conference, 25-27 September, Daegu, South Korea.

Lundvall, B. A., Vang, J., Joseph, K. J., \& Chaminade, C. (2009). Innovation system research and developing countries. In Lundvall, B.A., Joseph, K.J., Vang, J, \& Chaminade, C. (Eds.), Handbook of innovation system and developing countries (1-30). Cheltenham: Edward Elgard.

Malerba, F. (ed). (2004). Sectoral system of Innovation: concept, issues and analysis of six major sectors in Europe. Cambridge: Cambridge University Press.

OECD. (2015). Frascati manual 2015: Guidelines for collecting and reporting data on research and experimental development, the measurement of scientific, technological and innovation activities. Paris: OECD Publishing.

Pappiptek-LIPI. (2013). Innovation survey in manufacturing 2011. Jakarta: Pappiptek-LIPI.

Pappiptek-LIPI. (2014). Indonesian S\&T Indicators. Jakarta: Papiptek-LIPI.

Rammer, C., Czarnitzki, D., \& Spielkamp, A. (2008). Innovation success of non-R\&D-performers substituting technology by management in SMEs (Discussion Paper. No. 08-092). Mannheim: Centre for European Economic Reserach (ZEV). 
Robertson, P. \& von-Tunzelmann, N. (2009). Innovation in low and medium-technology industries: introduction. Research Policy, 38, 441-446.

Santamaría, L., Nieto, M. J., \& Barge-Gil, A. (2009). Beyond formal R\&D: Taking advantage of other sources of innovation in low- and medium-technology industries. Research Policy, 38, 507-517.
Som, O., Kirner, E. \& Jager, A. (2013). Absorptive capacity of non-R\&D-intensive firms in the German manufacturing industry. Paper presented at the 35th DRUID Celebration Conference, Barcelona, Spain, June 17-19.

Tsai, K. H. \& Wang, J. C. (2009). External technology sourcing and innovation performance in LMT sectors: An analysis based on the Taiwanese technological innovation survey. Research Policy, 38, 518-526. 